\title{
Utilitarianism and the Challenges of Insecurity in Nigeria from 2015 to 2019
}

\author{
Adebayo, Williams Adewumi (Ph.D) $)^{1^{*}} \quad$ Adeniyi, Adebola Olumide (LL.M) ${ }^{2 * *}$ \\ 1.Department of Business and Industrial Law, Faculty of Law, Ekiti State University, Ado-Ekiti, Nigeria \\ 2.Department of Public Law, Faculty of Law, Ekiti State University, Ado-Ekiti, Nigeria.
}

\begin{abstract}
One defining character of Nigeria federalism is the heterogeneous nature comprising of over two hundred and fifty ethnic nationalities with diverse culture, religion and values. The current population of Nigeria is $199,617,970$ based on the latest United Nations estimate. The country experienced a chequered history due to incessant military intervention after independence in 1960.The military finally relinquished power on the $29^{\text {th }}$ May, 1999 and since then, Nigeria has been plunged into one form of insecurity or the other. Hopes of better days ahead grow dim everyday and in 2015 , insecurity was the campaign slogan against the then incumbent government and the political party that assumed power on $29^{\text {th }}$ May, 1999(The Peoples Democratic Party). The need for change was hinged on insecurity in view of the spate of violence causing deaths and destruction of properties from the acts of terrorism, banditry, ethnic clashes etc. The event from 2015 to 2019 has shown a geometric rise of the level of insecurity in Nigeria while other forms of insecurity have emerged. There are laws, security outfits as well as a legitimate government in place and yet the lives and properties of people are daily in danger. The objective of this study is to proffer solutions to the challenges of insecurity. The challenges of insecurity are placed at the doorstep of the government and the process of decision-making. The study recommends the application of the utilitarian ethics as a compass to chart the path of security to avoid senseless carnage that is a threat to the corporate existence of the nation.
\end{abstract}

Keywords: Utilitarianism, insecurity, terrorism, banditry, altruism etc

DOI: $10.7176 / \mathrm{JLPG} / 86-07$

Publication date:June $30^{\text {th }} 2019$

\section{Introduction}

Utilitarianism is an ethical and philosophical theory that states that the best action is the one that maximises utility, which is usually defined as that which produces the greatest well-being of the greatest number of people, and in some cases, sentient animals. It is a version of consequentialism which states that the consequences of any action are the only standard of right and wrong. Unlike other forms of consequentialism, such as egoism and altruism, utilitarianism considers the interests of all beings equally ${ }^{1}$. The challenges of insecurity in Nigeria are not external but internal and are caused by Nigerians. Insecurity was the major slogan that the government sworn -in on the $29^{\text {th }}$ May, 2015 employed to win elections in 2015 to displace the government of the Peoples Democratic Party that had been in power since 1999. The masses particularly, the people from the North Eastern zone in Nigeria and Nigerian generally were optimistic that the long-awaited messiah with the magic wand to curb the challenges of insecurity had emerged. Threats to lives and properties have always existed in Nigeria but Nigeria before 1999 had not been a pariah state to the other nations as it is today. Foreign embassies from 2009 to date have been in the habit of issuing caution to tourists from their home country not to travel to some parts of the country because of insecurity. The caution is not abnormal in view of the deaths of many foreigners arising from insecurity in Nigeria. Crimes attracting capital punishment in Nigeria before 1999 were limited to crimes like armed robbery and intentional killing of other persons. These crimes were not as frequent as we have them in Nigeria today. Boko Haram insurgency was the greatest threat to security before 2015 and it was the only terrorist act that accounted for the decimation of the greatest number of people that died between 2009 and 2015 . Armed robbery which was the major crime in Nigeria before 2009 was not carried out with the intention to kill but for pecuniary reason. Hired assassination was also another form of threat to life in the period before 2015 and it was directed against perceived political opponents. However, from 2015 to date, insecurity has cast a shadow on the happiness of the greatest number of the people. The increase in the intensity of operation of Boko Haram insurgency has resulted in the aggravated loss of human lives, displacement of people and destruction of properties. The Fulani herdsmen and farmers clashes were relatively unknown before 2015 and where it existed, it was not with the magnitude of loss of lives and properties as it is today. Ritual killing and cultist activities reminiscence of the state of nature and prevalent and have become headlines in the daily newspapers and electronic media in Nigeria. Kidnapping for ransom which started in the Niger-Delta areas, the oil producing region in Nigeria, has spread to every part of Nigeria. Vandalisation of oil pipelines; communal clashes; spouse bashing, and armed robbery now occur frequently in Nigeria. Terrorist act of Boko Haram in the North-Eastern

\footnotetext{
${ }^{1}$.Utilitarianism.<ps://en.m.wikipedia.org> accessed 27 March, 2019
} 
part of Nigeria; the Fulani herdsmen and farmers clashes in the middle-belt region of Nigeria and armed banditry operation in Zamfara, Kebbi, Kaduna and Katsina States in the North-West region have resulted in the destruction of villages and properties leading to displacement of hundreds of thousands of people from their ancestral villages and painful deaths. The displaced people from this theatre of conflicts are now accommodated in the Internally Displaced Peoples Camps where they depend on humanitarian assistance for survival.

This study is divided into five parts. Part one is the introduction which is a summary of the security challenges in Nigeria from 2015 to date while part two is the discussion on Nigeria. Part three is a discussion of utilitarianism. The challenges of insecurity in Nigeria are discussed in part four. The utilitarian compass for combating insecurity is the content of part five which identifies those strategies that will help in good decisionmaking that will help to tackle the challenges of insecurity in Nigeria. The final part is the conclusion

\subsection{Nigeria at a Glance}

Nigeria is a federation of over two hundred and fifty ethnic nationalities with each nationality exhibiting diversities in religion, culture, custom and moral values. The geographical entity now described as Nigeria was until October, 1 1960, a colony of Great Britain with the Queen of England as the head of State. The Northern and Southern protectorates administered by the British colonial masters were amalgamated to become a single country in 1914. Nigeria became an independent nation on the $1^{\text {st }}$ of October, 1960 and a republic on the $1^{\text {st }}$ of October, 1963. Nigeria until 1966 was structured into three regions- the Northern Region, the Western Region and the Eastern Region. Each of the regions then had its own Constitution and was financially independent. Each region developed at its own pace without any conflict between the region and the Federal Government. The parliamentary system of government adopted at independence existed till 1966 when the military overthrew the civilian government. Nigeria was divided into twelve states in 1967 and later increased to nineteen in 1976. Two additional states were created in 1987 to make the states twenty-one. On August 27, 1991, nine additional States were created to increase the States to thirty and on the $1^{\text {st }}$ of October, 1996, General Sanni Abacha, the then military Head of State created additional six states which now makes Nigeria a federation of thirty-six states and the Federal capital Territory. There are also six geo-political zones namely the North-West, the North-central and the North-East, the South-West, the South-East and the South-South.

The three major ethnic groups in Nigeria are the Hausa/Fulani; the Yorubas and the Igbos. There are other minority groups located across the various parts of the country with distinct languages, religion, cultures and values. Nigeria operates a federal system of government comprising the federal, state and local governments. There are also three arms of government, namely the executive, the legislature and the judiciary at both the federal and state levels. The legislature at the federal is bicameral comprising the Senate and the House of Representatives while the legislature at the States is unicameral and known as the House of Assembly. The judiciary in Nigeria consists of courts listed in the 1999 Constitution as superior courts of record ${ }^{1}$. There are other courts not listed in the Constitution but which are known as inferior courts. The Supreme Court is the apex court and the final court in Nigeria and it is headed by the Chief Justice of Nigeria. The Independent National Electoral Commission (INEC) is the body responsible for the conduct of elections in Nigeria under the Electoral Act. The State Electoral Commission is saddled with the responsibility of conducting elections into the Local Government Councils.

\section{Utilitarianism}

Utilitarianism is one of the most powerful and persuasive approaches to normative ethics in the history of philosophy. Utilitarianism when applied to law is a functional approach to the understanding of law by observing its basic tenets and purpose in the society. It is an ethical and philosophical theory that states that the best action is the one that maximises utility, which is usually defined as that which produces the greatest well-being of the greatest number of people and in some cases, sentient animals...it is a version of consequentialism which states that the consequence of any action are the only standard of right and wrong ${ }^{2}$. Furthermore, consequentialism holds the view that the consequences of a decision, deed, or policy determine its moral value. If an action produces better consequences than the alternatives, then it is the better action, morally speaking ${ }^{3}$. To the utilitarian philosopher, if an act will produce more happiness than will alternatives, it is the right to do and if it will produce less happiness, it would be wrong to do it in the place of an alternative that would produce more happiness. In short, act so as to produce the most happiness ${ }^{4}$. Utilitarian weigh the consequences of alternatives, pro and con and then choose the alternatives that maximise happiness ${ }^{5}$. The philosophers view that the morally

\footnotetext{
.Chapter Six, 1999 Constitution of the Federal Republic of Nigeria as amended

. https://en.m.wikipedia.org/wiki.utilitarian accessed 27 March 2019

. Brooke Noel More and Richard Parker, Critical Thinking, (McGraw Hill Education 2007)

.ibid

5 ibid
} 
good action is the action that produces the most $\operatorname{good}^{1}$. It holds that the most ethical choice is the one that will produce the greatest good for the greatest numbers ${ }^{2}$. The utilitarian school of jurisprudence considers that utility is the standard for measuring the propriety of our conduct and approach.

Utilitarianism has made immense contributions to the understanding of the place of law in society and in decision-making process by the government. Jeremy Bentham (1748-1832) and John Stuart Mill (1806-1873) are the most important classical utilitarian and social reformers. The theories of these philosophers had a major impact in moral theory and approaches to economic, political and social policy. Bentham posited that the function of law in society should be the provision of the greatest happiness of the greatest numbers ${ }^{3}$. Utilitarian can be classified as either act utilitarian or rule utilitarian. Both act utilitarian and rule utilitarian agree that our overall aim in evaluating actions should be to create the best results possible, but they differ about how to do that Act utilitarian believe that whenever we are deciding on what to do, we should perform the action that will create the greatest net utility. The principle of utility is to do whatever the overall best results. The right action in any situation is the one that yields more utility than other available actions. Rule utilitarian adopts a two part view that stresses the importance of moral rules. According to rule utilitarian, a specific action is morally justified if it conforms to a just moral rule; and a moral rule is justified if its inclusion into our moral code would create more utility than other possible rules. According to this perspective, we should judge the morality of individual actions by reference to general moral rules, and we should judge particular moral rules by seeing whether their acceptance into our moral code would produce more well-being than other possible rules ${ }^{4}$.

Bentham is of the view that the task of laws should be to bring about the maximum happiness of each individual, for the happiness of each individual will result in happiness for all. To the utilitarian, the essence of law in the society is that it is a means of ensuring the happiness of the members of the community generally ${ }^{5}$. Classical utilitarian believes that law must focus on the individual. The main idea is that society is rightly ordered, and therefore just, when the major institutions are arranged so as to achieve the greatest net balance of satisfaction summed over all the individuals belonging to it $^{6}$. The society-oriented utilitarian canvasses that the interest of the individual must be subordinated to that of the society at large. An individual member of the society should be afforded the means of pursuing his legitimate interest so that he can also contribute his own quota to the development of the society. As posited by the individual utilitarian, the well-being of a person is constructed from the series of satisfactions which are experienced at different moments in time and which constitute the life of the individual, so the well-being of society is to be constructed from the fulfilment of the system of desires of the many individuals who belong to it. Since the principle for an individual is to advance as far as possible the welfare of the group, to realize to the greatest extent the comprehensive system of desire arrived at from the desires of the members ${ }^{7}$. To the individual utilitarian, it is possible for an individual to balance present and future gains against present and future losses, so a society may balance satisfaction and dissatisfactions between different individuals. This approach will help to shape government policies at the national level. A society, the utilitarian believes will be properly arranged when its institutions maximise the net balance of satisfactions ${ }^{8}$. An individual member of the society may choose to invest his present income on selfdevelopment by further education that will enhance his status in society rather than consuming the income on lustful passion. The social security system for the elderly and the unemployed youths is a way of balancing satisfactions and dissatisfactions between the different classes of people in the society. The scholarship scheme for students; the amnesty programme for militants; free-feeding programme etc in Nigeria are all appeal and application of the utilitarian tool towards the challenges of the society.

Bentham recognizes the pivotal role of law in ordering the society. He was a positivist and therefore he detests the tenets of the natural law school. To him, anything that is beyond human observation is not worthwhile. He disagreed with the transcendental system of the immutability of law. Law can be used as an electronic remote control to determine the behaviour of man. His theory of felicific calculus is predicated on the balancing of individual interests with communal interests. Man, according to him, is under the guidance of two sovereign masters which are pain and pleasure. Man would naturally refrain those activities that would cause him pain while he would always pursue those activities that give him pleasure. He advocated that laws should be made which would make anti-social behaviour unprofitable, in other words, a source of pain to the doer rather than the source of pleasure. In censorial jurisprudence, he argued that the foundation of the legal reasoning of the legislators should be the public good. A piece of legal instrument, he opined, should advance the happiness of society. As a social utilitarian, Bentham believes that the society must be given priority over the individual. His

\footnotetext{
https://plaato.stanford-edu <entries> utility> accessed 27 March 20119

2 .https://ethicsunwrapped.utexas-edu accessed 27 March 2019

.R.W.M Dias,Jurisprudence. (Butterworths Publishers 1985)

${ }^{4}$.https://www.iep.utm.edu accessed 27 March 2019

5 .R.W.M Dias, $O p$. cit

${ }^{6}$. John Rawls. A Theory of Justice (. Oxford University 1980)

Ibid pp 23-24

${ }^{8}$ Ibid p.24
} 
hedonistic calculus is a method of assigning actual numerical values to pleasures and pains based on their intensity, certainty, duration and so forth.

The modern day government of whichever form is confronted with the challenges of making choice in decision-making. At the international level, the choice of relations is determined by the happiness or the benefits. The masses in making their choices as to who to elect during elections are guided individually by the principle of what they believe will bring happiness and not pains. The three arms of government, that is, the legislature, the executive and the judiciary have to take decisions which will go a long way to determine social order, peace and security. As pointed out, utilitarian weigh the consequences of alternatives. The decision on legal instruments, policies and the justice of a cause will either mar or make the society; create order or disorder. The state of peace or war, development or underdevelopment; prosperity or poverty; justice or injustice in a sovereign nation is a function of the right or wrong decision made in the past by the leaders and in a democracy, whether the society will develop is a function of the choice of the electorates.

\subsection{The Challenges of Insecurity in Nigeria}

That democracy is a government of the people by the people and for the people is a statement that admits of exception in virtually all African countries. The premise of this conclusion is unassailable considering the spate of acrimony, bloodshed, instability, military intervention among other negative features that have characterised the political landscape of Nigeria from 1960 when Nigeria attained independence till date. The beauty of democracy is for the masses to be positioned to elect the people that will be entrusted with power in free, fair and credible elections. Insecurity is one of the fallouts of faulty democratic process. Nigeria has been struggling to get it right; however, every step taken has failed to yield any positive result. The 2015 general election, even though with all its irregularities, was a pragmatic step to deepen the democratic process in Nigeria through the exemplary leadership of the then incumbent president who campaigned against violence and bloodshed in the election that ousted him. The decision of the president then averted an imminent state of anarchy and it was given accolade by the international community as the most patriotic act expected of a statesman. The events from 2015 to date and all the elections that have been conducted to the 2019 general elections demonstrate in an unambiguous term that Nigeria has retrogressed from the path of credibility of a democratic process. The electoral umpire abandoned the people who are the ultimate source of sovereignty through the introduction of strange rules meant to satisfy the government. The rule of inconclusive election from 2015 has been employed by the electoral umpire to perpetrate day light robbery and to render the votes of the people nugatory and of no significance. The fallout of the decisions taken by government and the agencies of government are the obvious and visible challenges to good governance and the cause of insecurity in Nigeria. The decision-makers in government whether in the executive or the legislative arm are products of faulty electoral process. The preparation for the 2019 elections started in 2015 but the flaws that characterised the 2019 election such as the unnecessary postponement of elections, declarations of election as inconclusive, violence, arson committed against the property of the electoral body, snatching of ballot boxes, vote buying etc show clearly that the electoral process is not transparent, credible and fair. The card reader was a strategy to give credibility to election but the rule was applied according to the whims and caprices of the electoral body. The card reader is designed to prevent under-age voting, double voting and over-voting. The mischief sought to be cured became prevalent and grew worse from 2015 to date. The Information Communication Technology Centre (ICT) branch of the electoral umpire has been accused of collusion as well as being an engine room of fraud. The problem of governance which has invariably resulted into insecurity is not about the rules but about what the human element does with the rules. The expected change continues to be elusive as the leaders and the people are not prepared to change from the old ways of doing things. The National Assembly in 2018 transmitted to the president for his assent, the amendment to the 2010 Electoral Act. The amendments proposed were designed to ensure credible election and transparent electoral process, but the president withheld the assent. The implication of the style and methods of governance in Nigeria is that decisions are not taken in the interest of the people but rather to satisfy the immediate interest of the ruling class. The electoral process is designed from pregnancy to be a tool in the hands of the ruling class and as long as it is so, the democratisation process will continue to suffer credibility. The members of the electoral body are the appointees of the government and they enjoy their tenure at the pleasure of the executive. The electoral process is militarised while large cache of weapons are in the possession of political thugs employed by politicians.

The incidence of ballot snatching, destruction of ballot papers/boxes, vote buying, militarisation of the electoral process, thuggery, assassination of political opponents, burning down of electoral materials and offices of the Independent Electoral Commission are symbolic of a failed system that is bound to produce enormous security challenges for good governance. The lack of transparency, credibility, fairness and other vices are the greatest act of injustice that a citizen can suffer in a democracy and in the absence of immaculate and impartial judiciary, the recourse to illegality becomes the only option for the people to express their dissatisfaction. The judiciary in Nigeria cannot pontificate as it is enmeshed in corruption saga and the few that are not corrupt only 
exist to blow muted trumpet. The executive in Nigeria is not prepared to accept the judiciary as an independent arm of government. The executive is always ready to go to any length to bring the members of the judiciary to their kneels where they are perceived to be uncompromising. The case of the Chief Justice of Nigeria, Justice Walter Nkannu Onnoghen, the former president of the Court of Appeal, Issa Salami, the Chief Judge of Kwara State, Justice Elelu Habeeb, the Chief judge of Kogi State, Justice Nasir Ajana etc are all instances of attempt to suppress the members of the judiciary. The feeling that the judiciary is no longer the hope of the common man and that the judiciary is subject to the dictate of the executive make it imperative for the breeding of recidivists.

Democracy in Nigeria today is similar to the scenario during the first republic. .During the first republic, national leadership in Nigeria tended to be essentially personality cults. The strongman or the charismatic personality emerged and provided a centripetal force attracting henchmen to self. Leadership then thus tended to draw its essence or relevance and even legitimacy from ethnic or tribal considerations. Tribe was the leverage. Tribe was the polar star... Leadership was idolized and transmuted into semi or demi-gods or supermen. During the period we produce a large pool of sycophants and hosanna chanters who were very quick to the basal sentiments of the leadership ${ }^{l}$.

The expectation of the society from every elected government is the security of lives and properties. The government is equally expected to do justice which is the virtue of social institutions. A theory, however , elegant and economical, must be rejected or revised if it is untrue; likewise laws and institutions, no matter how efficient and well arranged must be reformed or abolished if they are unjust ${ }^{2}$. The people are the source of sovereignty in Nigeria $^{3}$. The people who are the donor of sovereignty expect from the donee the security of lives and property which is necessary to enable them move about in pursuit of their daily activities without which they will not be able to support the government further. The government having been instituted expects the society to discharge certain obligations for the smooth running of the government, one of which is the payment of taxes. Without the guarantee of security, there is no way the society can perform their obligations. The truth is that it will always be in the best interest of the government to ensure adequate security; otherwise, the society will be constrained to depend on the government for survival instead of the society supporting the government. The social order is one of the fundamental objectives and directive principles of state policy in Nigeria and it is founded on the ideals of freedom, equality and justice. In furtherance of the social order, the government is mandated to recognise the sanctity of human person and at the same time maintain and enhance human dignity. In Nigeria, every person has a right to life and no one is to be deprived intentionally of his life, save in execution of the sentence of a court in respect of a criminal offence of which he has been found guilty in Nigeria ${ }^{4}$. Democracy as practised in order clime is a propeller for social, economic and political development. What the electorates demand is not any form of gratification. The demand of the people is the atmosphere which promotes security which invariably enable the people practice their vocation and earns their living. However, from 2009 till date, insecurity has crippled the ability of the people to contribute their quota to nation building.

Security is the backbone of human development. Security as used in this study refers to the protection of lives and properties from any violence that can lead to death or destruction of property. It is the existence of the conditions within which people in a society run their normal daily activities without any threat to their lives and properties. Insecurity in any sovereign nation is an evidence of fundamental breach of trust by the elected representatives in government. Though the task of security is not the exclusive responsibility of government, but rather a combined duty of government and the masses, the government is primarily responsible and should chart the course for adequate security. Insecurity is a symptom of lack of confidence and a challenge to the legitimacy of the government of the day. There is no nation in the world that does not experience one form of criminal activities or the other that can threaten insecurity, however, where a nation is confronted with the spate of violence that manifests in different forms and occurs frequently or incessantly without any assurance of when it will end, the nation is considered insecure. One prevailing act of violence can lead to insecurity just as the insurgency in Syria, Iraq and Somalia etc. Also a complex variety of acts of violence persistent without any assurance of immediate end can bring a nation within the parameter of insecurity. Nigeria is a very good example of a complex variety of acts of violence. The acts that threaten the security of Nigeria include the Boko Haram terrorism; the Fulani herdsmen/farmers clashes; kidnapping; ritual killing; cultist activities; armed banditry and armed robbery.

(a)Boko Haram Insurgency- Boko Haram (Western education is sin) has its root in the North Eastern States of Nigeria and it is the greatest source of terror and horror to the people of Nigeria and other neighbouring West African countries such as Cameroon, Chad and Niger. It is the greatest security challenge facing Nigeria as a sovereign nation. From 2009 when the operation of the sect assumed a violent dimension, Nigeria has suffered untold hardship by the destruction of lives and properties of people. Boko haram operation in the three north

\footnotetext{
. T. David -West, A Critique of National Leadership in Nigeria: Philosophical Essays (Ibadan University Press 1980)

2 . Rawls, Op. cit

3 .CFRN 1999,s14

${ }^{4}$.CFRN 1999 s33(1)
} 
eastern states of Borno, Yobe and Adamawa has forced over one million people to become homeless and are now living as refugees in Internally Displaced Camps (IDP) in the region. The degradation of the environment from the insurgent activities and the destruction of houses and farmlands in the states have made it practically impossible for the people to practice their vocation, hence they have to depend on the government and charity for survival in the camps. Boko Haram insurgency is carried out by Islamic fundamentalists pressing for the establishment of a state based Sharia law. The riddle remains unresolved why the operation of the sect is indiscriminate considering the attacks on both adherents of Islamic and Christian faith. Churches and Mosques, Christians and Muslims, women and men, young and old, traditional rulers and the common people are attacked indiscriminately. The point must be made that though members of the sect are Muslim, it does not mean that all Muslims are fundamentalists and most fundamentalists are not terrorists, but most present day terrorists are Muslims and proudly identify themselves as such ${ }^{1}$. Fundamentalists detest everything western and are opposed to the secularist ethos of modernity. There is a world of difference between a fundamentalist and a fanatic. Religious fanatics hold firmly to their faith and do not employ any force to persuade or convert people of other faith like the fundamentalists. Fundamentalists believe in the use of terrorist act to achieve their goal. Terrorism connotes the intentional and deliberate act of violence towards civilian populace and even the security forces with a view of instilling fear into the government as a means of pursuing a political goal. Boko Haram had existed as a Muslim Youth Organisation called Shabaab in 1995 under the founder, Abubakar Lawan, an Islamic cleric. Ustaz Mohammad Yusuf, a close ally to Lawan assumed leadership of the sect after the departure of Lawan to Medina for further studies at the University of Medina in Saudi Arabia. The sect under the leadership of Yusuf attracted swarm of youths of Islamic faith from the North-East region and other neighbouring countries such as Chad, Cameroon and Niger republic. Yusuf established a religious centre which included a mosque and a school which offered primarily ideological studies ${ }^{2}$.The goal of the sect under Yusuf was the establishment of an Islamic state in Nigeria through dialogue; however, the sect adopted a radical and violent approach in retaliation for what they perceived as police brutality against the member of the sect. The sect in December 2003 carried out the first violent attack with more than 200 members attacking different police stations in Yobe State, near the Niger border. The sect had a major confrontation with the military in 2009 in which approximately 800 to 900 militants were killed ${ }^{3}$.Ustaz Mohammad Yusuf was captured during the fracas by the military which later handed him over to the police. Ustaz Mohammad, however, died while in the custody of the police in a circumstance suspected to be an act of murder by the police. The death of Mohammad paved the way for Abubakar Shekau to become the new leader of the sect. The leadership of Shekau from 2009 till date has brought holocaust and sorrow mainly to the people of the North Eastern region of Nigeria and the northern part of Nigeria generally. The magnitude of carnage and the intensity of operation of the sect under Shekau made the United Nations to declare the sect as one of the deadliest extremist groups in the world. The sect like all other terrorists thrive in the adversity of the victims, hence attacks are carried out on strategic locations. Operational targets include but not limited to educational institutions, worship centres, markets, motor parks, malls, government offices, security posts, police stations and army barracks. In 2014, the sect abducted about two hundred and seventy six(276) female students of Government Secondary School, Chibok in Borno State. Some of these girls were released while over one hundred are still in the custody of the sect. In 2018, the sect equally abducted one hundred and five (105) girls from the Government Secondary School at Dapchi in Yobe State but the sect released the girls few days later after the intervention of the government. The sect, however, refused to release one of the girls, Leah Sharibu for refusing to denounce her faith as a Christian.

The difficult terrain of the Sambisa forest in Borno State; the affiliation of Boko Haram to the Islamic State of Syria and Iraq (ISIS); attacks on soft targets and lack of modern and sophisticated weapons make the war against Boko Haram a herculean task for the Nigeria military to win. There is also the theory of conspiracy between the military, particularly the members of the armed forces who are of the same ethnic and religious faith with the members of the sect. For instance, it is alleged that not less than seventy percent of the natives of Damboa town in Borno State belong or have sympathy for the cause of the sect. There is also the conspiracy of top northern politicians with the sect. The politicians have been accused of providing logistics support for the sect. The suicide bombing strategy of the sect has made the operation of Boko Haram more catastrophic considering the number of deaths, injuries to life and the destructions of properties in every operation. The purpose of killing and destruction of villages remains a conundrum in view of the goal of the sect which is to establish a Sharia state. The Sharia law can only be enforced in a human society and not on people displaced from their habitation. The sect embarked on vicious attacks on military and police formations in 2018. On 26 July, 2018, Boko Haram fighters stormed a base on the outskirts of Jakana, a village which is 30 kilometres from

\footnotetext{
${ }^{1}$.Badey, Thomas J, 'Violence and terrorism(07/08) In :Dubuque, I A (ed) Mcgraw-Hill Contemporary Learning Series (2007). See also< https://trove.nla-gov.au/version/39371702>

2. Muhammad Fayazz, 'Understanding the Intensity of Boko Haram Terrorism' (2015). <https://globalecco.org/343 accessed 21 February 2019

3 .ibid
} 
Maiduguri, the capital of Borno State. They took control of the military base with the aid of sophisticated weapons after overpowering the soldiers. The sect stormed the military base in a military fatigue around $6 \mathrm{p} . \mathrm{m}$ and operated for more than three hours with heavy casualties on the side of the armed forces ${ }^{1}$. In the same month, the sect attacked a military convoy before attacking a military base and scores of soldiers from 21 Brigade were displaced while ten corpses were recovered after the skirmishes. Around the same period, the jihadists in their huge number overwhelmed the 81 Division Forward Brigade located at Jilli, Geidam during which time the base lost some of its equipments to the insurgents. The base reportedly had over 700 personnel with most of them just deployed from Lagos in the South West to the theatre of war. At the end of the encounter which lasted for over two hours, the troops that survived were less than one hundred ${ }^{2}$.Boko Haram operation has spread beyond the three north eastern states to virtually all the northern states and the neighbouring countries of Cameroon, Chad and Niger Republic. The hope of winning the war against insurgency of Boko haram is daily becoming a mirage in view of the affiliation of the sect with the Islamic State of Iraq and Syria (ISIS) forces. Boko Haram is now split into two factions, one is known as ISIS West Africa and the original sect under the leadership of Shekau. Both factions have continued to enjoy support from the Middle-East and from top Nigerian politicians in terms of finance and supply of sophisticated weapons. The government needs to take decisions that will bring the greatest happiness to the greatest number of Nigerians and evolve policy that will stop the senseless loss of lives that has turned Nigeria to abattoir of human souls.

(b)Fulani Herdsmen and Farmers Clashes- Fulani herdsmen are traditionally itinerant cattle breeders and have co-existed with the hosts of every location in Nigeria peacefully before the advent of the government of Mohammed Buhari. Nigeria woke up to the new face of herdsmen in Nigeria bearing sophisticated weapons like AK 47 rather than the traditional shepherd staff. The Fulani herdsmen and farmers clashes in Nigeria have brought untold sorrow to humanity by the carnage to human lives and properties. The states mostly affected in Nigeria are Benue, Plateau, Kaduna and Zamfara States where hundreds of villages have been decimated and farmlands destroyed completely. The use of the word "clash" has been described as a misnomer in view of the style of attacks. The carnage is described as one-sided unprovoked attacks launched by the Fulani herdsmen. There is the doubt as to whether the killers are actually herdsmen as they always operate in military fatigue attacking with sophisticated weapons against helpless villagers. The sect operates in a commando style in the dead of the night devastating communities where they operate while the villagers who have no inclination as to the attacks are killed in hundreds while the lucky ones who escape suffer one degree of injury to another. The attacks by the suspected herdsmen have been interpreted to mean an act of genocide and as at the time of this study, the former president of Nigeria, Chief Olusegun Obasanjo described it at "Fulanisation and Islamisation of Nigeria". This conclusion becomes irresistible because of the pronouncements and the activities of the Fulani associations after every attack. The umbrella association of the herdsmen (Miyetti Allah) has on several occasions justified the attack and after each attack, they are found of taking over the villages or farmlands of their victims. The president of Nigeria in one of his reactions alleged that the people behind the attacks are the Fulani herdsmen from the neighbouring West African countries even when the umbrella association of the herdsmen claims responsibilities. The President in another occasion called for the abrogation of the Anti-Open Grazing Law enacted by some states as a way to resolve the conflicts. The apathy of the Federal Government to the plight of the victims of the assault by herdsmen and the body language of the government encourage the attacks and make the commission of crimes a source of pleasure rather than pain. Abrogating the Anti-Grazing Law by states as demanded by the presidency is considered to be a tacit support for the herdsmen who are of the same ethnic group with the president. Herdsmen have attacked states like Plateau, Nassarawa, Taraba, Kaduna etc without Anti-Open Grazing Law. The attacks therefore are not motivated by any legal instrument considered to be against the interest of the herdsmen. The escalating conflict between herdsmen and farmers in Nigeria is six times deadlier than the Boko Haram attacks ${ }^{3}$. In January, 2018 as many as 300 Nigerians were reported to have died in a wave of violent killings. The farmer-herder conflict has become Nigeria's gravest security challenge, now claiming far more lives than the Boko Haram insurgency. It has displaced hundreds of thousands and sharpened ethnic, regional and religious polarisation. In June, 2018, at least 86 people were killed in a week long attack in Plateau State while in Benue State, 72 people died in a New Year's Day massacre after the implementation of the Anti-Open Grazing Law in Benue State ${ }^{4}$. In April, 2018, Saint Ignatius Catholic Church in Mbalom, Benue State was attacked by people suspected to be Fulani herdsmen in a morning mass attended by

\footnotetext{
1 .'Four soldiers, two policemen among 13 killed by Boko haram Attack in latest Boko Haram Attack' < saharareporters.com> accessed 11 April 2019

2 .https://punching.com>boko-haram; https://www.aljazeera.com>news >; 'Many soldiers killed, injured as Boko Haram invades military bases in Borno', <saharareporters.com>2018/12/16>; Boko Haraam attacks major military base in move to control territory. https://www.premiumtimesng.com, accessed 11 April 2019

3 . Bukola Adebayo, 'Nigeria 's Pastoral conflicts Six times deadlier than Boko Haram in 2018' https://edition.cnn.com/2018/07/27/africa/Nigeria-herdsmen <accessed 11 April 2019>

${ }^{4}$.ibid. International Crisis Group (ICG) https://edition.cnn.com/2018/07/27/africa/nigeria-herdsmen-boko-haram-report accessed 11 April, 2019
} 
worshippers. The attack resulted in the death of 19 people including Reverend Fathers Joseph Gor and Felix Tyolaha who were holding the morning mass after the attack, the invaders descended on the community and razed over sixty houses, farmland, food barns, after carting away what the people had in the barns ${ }^{1}$.

(c)Armed Banditry- Armed banditry is another threat to the security of lives and properties in Nigeria. It is a species of terrorist act. It is not a clash between two opposing religious groups, ethnic groups or farmers and herdsmen. It is an act perpetrated by some criminally minded people suspected to be a splinter group of Boko Haram. They engage in cattle rustling, kidnapping and armed robbery. The stronghold of armed banditry in Nigeria is Zamfara State, which was the first state in the northern region to implement the Sharia law. Other States experiencing armed banditry are Katsina, Kebbi and Sokoto States. The Nigerian Minister of Defence, Brigadier-General Mansur Dan-Alli (rtd) alleged that the bandits had links with the Boko Haram. The bandits are usually heavily armed and they move in large numbers attacking both during the day and in the night. Armed banditry is another burden to the weight of insecurity in Nigeria in view of the number of lives lost daily. On 26 March, 2019, Dr. Jang Sunail, a Korean expatriate doctor was abducted by bandits in Tsafe town, Zamfara State. Between 2011 and 2018, about 1321 people were alleged to have been killed in banditry operation alone in Zamfara State with 1881 people injured, 185 cars and motorcycles lost. In the same period, ten thousand herds of cattle were lost to rustling; 2,688 hectares of farmlands and 10,000 houses destroyed. The Governor of the State , Abdulaziz Yari in 2018 expressed his helplessness by calling on the Federal Government to declare a State of Emergency in the State ${ }^{2}$. The National Assembly urged the Federal Government to mount diplomatic pressure on Niger Republic and Chad to prevent criminals from using their territories to launch attacks on Nigeria. The upper chamber also urged Zamfara State to upgrade recruit and to generously fund state and local vigilant teams with the aim of improving security in the affected states ${ }^{3}$.

(d)Kidnapping- In Nigeria, apart from road accidents, kidnapping is another source of nightmare on the Nigeria public highways. Kidnapping of people for ransom has replaced armed robbery on the highways. Kidnapping is the abduction or holding people hostage either to take ransom or for ritual killing. Kidnapping has altered the ways of life of the people to the extent that people can no longer engage in frolics. Movements are reduced to the ones that are absolutely necessary. People now abandon their private cars for public transport. The decision to patronize public transport appears not to be the solution in view of instances in which kidnappers have hijacked commercial buses with the passengers on the highway. Kidnapping in Nigeria was initially used as a weapon of protests by the people of the Niger-Delta area against the government and the Oil Producing Companies for the degradation of their environment and the neglect of the region by the Federal Government. The initial target and victim were the expatriate oil workers and high profile government officials. In Nigeria today, anybody can be kidnapped. Kidnapping has no regard for gender, age, religion, economic status, colour or nationality. Politicians, civil servants, lecturers, royal fathers, clergymen, traders, peasants, school children etc can be kidnapped at anytime. Kidnapping has spread from the southern states to virtually every part of Nigeria. Kidnapping has caused the untimely death of many people most especially where the victims are not able to meet the demands of the kidnappers. Kidnapping has continued to thrive in Nigeria because of poor security arrangements and poor democratic process. The leaders and the representatives in government cannot pontificate because of the process that brought them into power. The criminals and particularly those that have taken kidnapping as a profession are alleged to be the former employees of politicians. They were trained as political thugs and after election; they were abandoned to exist with the weapons given to them. The politicians are culpable for every act of terrorism in Nigeria. Kidnapping is a crime in Nigeria under several statutes; hence the prevalence and the upsurge in the rate of kidnapping in Nigeria between 2015 to date cannot be justified. The law enforcement agencies in Nigeria, particularly the police are not patriotic towards the need of national security. There are series of allegations against members of the Nigeria Police in which they are alleged to be informants and members of kidnap network. The Nigeria Police State Commands have units for anti-kidnapping but the impact of the unit is not felt considering the huge amount usually paid by the family members of victims as ransom. The Police and other security outfits in Nigeria have failed to take advantage of the devices provided by information technology in tracking criminals. In May, 2018, over 120 people were kidnapped between Friday $11^{\text {th }}$ and Tuesday $15^{\text {th }}$ May, 2018 along the Birnin Gwari-Kaduna road, Kaduna State. The second half of 2018 witnessed a daily occurrence of kidnapping in Nigeria. In Ondo State, the Akure/Owo/Akoko road became a nightmare for road users. On the $10^{\text {th }}$ of June 2017, the Police had a major breakthrough with the arrest of the notorious Evans, the kidnapper who has terrorised the whole country. He was in the police watch list for over seven years before he was arrested. In Ondo State, the government set up a joint security task force which penetrated the hideouts of kidnappers in the last quarter of 2018. The arrest by the task force revealed that over ninety percentages of the kidnappers are Hausa/Fulani from the northern part of Nigeria. The kidnappers that kidnapped the former Secretary to the

\footnotetext{
'Nigeria Mass Becomes a Massacre:Herdsmen kill 18 Worshippers, Adding to Hundreds of Victims'.Christianity Today. https://www.Christianitytoday.com/news/2018/april/nigeria/fulani-attack-catholic-church-benue accessed 11 April 2019

2 .'Special Report: No Security Strategy Despite Mass Killings in Zamfara'.<saharareporters.com/2019>accessed 11 April, 2019

3 .'Senate urges Zamfara to equip vigilance team to tackle killings', punchng.com.https://www.google.com accessed 11 April, 2019
} 
Federal Government, Chief Olu Falae are also herdsmen from the northern states. The kidnappers were arrested and prosecuted after which they were sentenced to imprisonment. The Director of the Lagos State Fire Services, Rasaki Musibau and six others were kidnapped along the Epe-Itokin Road, Ikorodu, Lagos on Saturday $6^{\text {th }}$ April, 2019. They were, however, released on Tuesday $9^{\text {th }}$ April, 2019. The security force was able to arrest two of the kidnappers. Kidnapping has impoverished the people in view of the huge sum of money usually paid as ransom before the release of victims. In most cases, families of victims are made to pay a minimum of Five million Naira and those who could not pay are wasted by the kidnappers. The challenge of kidnapping in Nigeria is a black spot on the ability of the government to use legal instruments to curb criminal activities in Nigeria.

(e)Ritual Killings- Ritual killing is another symptom of retrogression into the state of nature in Nigeria for the disregard to the sanctity of human lives. It is no longer an act perpetrated in the dark but a brazen act carried out by wicked people to appease their gods for riches, political appointments and favour. There are black markets in Nigeria for the sale of human parts at exorbitant prices. To avoid scarcity, baby factories are set up where babies are produced as raw materials for ritual killing. Ritual killing in Nigeria is carried out directly by abduction of victims or by indirect killing in which the victim is charmed or hypnotized. The indirect methods involve the use of the excreta or materials obtained from the body of the victim. In some cases, the semen obtained during the period of sexual intercourse with the female victim is used for ritual purpose. The victims of the indirect method usually develop strange sickness which eventually leads to their death. The culprits engaged in this act are the people styled as "Yahoo boys" in Nigeria. The Ondo State High Court on Tuesday March 26, 2019 sentenced to death one Seidu Adeyemi for killing his girlfriend, Khadijat Oluboyo, the daughter of the former deputygovernor of the State. The convict killed the victim and buried her inside his room ${ }^{1}$. In Arigidi-Akoko in Akoko North West Local Government Area of Ondo State, Nigeria, a 50 year old palm oil seller, identified as Iya Dunsi was reportedly murdered by ritualists, who removed her two breasts on Friday 12 April $2019^{2}$. Late Iya Dunsi, according to a police source, was kidnapped and her corpse was later found where it was dumped in a nearby bush.. Her assailants tied a rope on one of her legs and pulled her to the bush which is about 100 metres to her house. The year 2018 witnessed a new dimension to ritual killing in Nigeria. The attack was directed at the females particularly ladies who are forced to remove their pants at gunpoint. The pants after collection are used for ritual purpose. The menace has forced many ladies to dress without their underpants. The ritual killers in order to counter the strategy devised by ladies devised other means by going out with pants which ladies are forced to wear for about ten minutes after which the pants are collected back and used for ritual purposes. Ritual Killings is an affront to the right to life and the freedom of movement guaranteed by the Constitution of Nigeria. Travelling in the cities through commercial vehicles is as risky as travelling in private cars. It has even been discovered that some commercial vehicles operating in cities like Lagos,Ibadan, Akure, Port-Harcourt, Abuja etc are owned by ritual killers and whenever the vehicles are boarded by commuters, they usually end up in the den of the ritual killers. On 30 March, 2017 in Oyo State, a ritualist Tunde Jimoh was arrested after killing the victim, Akintoye Oyeyemi whose wrists, heart and legs were cut off. In 2016 at the Federal Capital Territory, a dismembered body of an unidentified lady was recovered at the lower Usman dam junction along Dutse, Bwari $\operatorname{road}^{3}$. A dreaded ritual killers known as "Badoo" emerged in Lagos State in 2018 and they unleashed havocs on the residents of Lagos State, particularly in Ikorodu area and the suburbs. They storm victim's residence at night while they are asleep during which time they use heavy grinding stones to crush the skulls of the victims. The blood and the brain from the victim are collected with handkerchief for ritual purpose. Killing for ritual occurs daily in Nigeria irrespective of the laws that criminalise killing.

(f)Armed Robbery- Armed robbery is as old as the history of Nigeria as an independent nation. The operation was mainly on the highway in which travellers are robbed of their valuables. Armed robbery on the highway is no longer common as the focus has been shifted to commercial banks in Nigeria. In every attack carried out against the banks, the victims are usually the customers, bank officials and the police. Armed robbery has caused the untimely death of many people in Nigeria apart from the fact that it has grounded the activities of many commercial banks.

\subsection{Utilitarian Compass for Combating Insecurity in Nigeria}

One of the salient terms in the Oath of Office sworn to by anybody elected as the President of Nigeria or Governor of any State in Nigeria is the well-being of the people captured as follows: .. and that I will devote myself to the service and well-being of the people of Nigeria ${ }^{4}$.

\footnotetext{
1 .'Killer of Ex-Ondo deputy-governor's daughter sentenced to death by hanging'. Pulsehttps://www.google.com accessed 28 March, 2019

2 .'Ritualists cut off 50-year old palm oil seller's breast in Ondo. Vanguard Newspaper https://www.vanguardngr.com accessed 28 March 2019

3 .' Why Killings for rituals are on the increase in Nigeria' Vanguard Newspaper https://www.vanguardngr.com/2017/09/killings-ritualsincrease-nigeria 1 March 2019

${ }^{4}$ CFRN $19997^{\text {th }}$ schedule
} 
The well-being of the people connotes and requires the government to uphold the provisions of the Constitution and particularly the provisions of the Fundamental Human Rights. Every person has a right to life and no one shall be deprived of his life, save in execution of the sentence of a court in respect of a criminal offence in which has been found guilty in Nigeria ${ }^{1}$.The killing of Nigerians for whatever reason is a violation of the right to life which the three arms of the government are expected to guard jealously. The social order in Nigeria is founded on the ideals of Freedom, Equality and Justice and in the furtherance of the social order, the sanctity of human person shall be recognized while human dignity shall be maintained and enhanced ${ }^{2}$. Every citizen of Nigeria has an obligation to respect the dignity, the rights and the legitimate interests of others and to live in unity and harmony and in the spirit of common brotherhood ${ }^{3}$. Governments world-wide are people oriented and no government can exist in vacuum. The provision of social infrastructure is only meaningful to the extent that they are for human beings to enjoy. Classical utilitarian posits that the well-being of a person is constructed from the series of satisfactions which are experienced at different moments in time which constitute the life time of the individual, so the well-being of the individual is to be constructed from the fulfilment of the system of desires of the many individuals who belong to $i^{4}$. The decision-making process of government can either make or mar the cause of justice. Utilitarian in government weigh the consequences of alternatives and then choose the alternatives that maximise happiness ${ }^{5}$. Insecurity is the major source of anguish in Nigeria. Decision-making involves the choice of alternatives from among a series of competing alternatives. Governance is an act; hence Plato advocated that the task of governance should be left for the philosophers. The Constitution of Nigeria makes it possible for people with little formal education to participate in governance. The qualification required for anybody to be a president and the Governor of a State respectively in Nigeria is the minimum of School Certificate or its equivalent ${ }^{6}$. The age requirement for the President, Governor and the Senate is now 35 years and for the House of Representatives and State Houses of Assembly is 25 years ${ }^{7}$. An aspirant is not required to have distinctions in all the papers attempted in the examination. What is required is that he participated in the examination. The decision not to amend the clause for academic requirement is not a decision tailored to improve the skill of decision-makers in government. The challenge of decision-making is the major impediment to the socio-economic and political development of Nigeria.

Bentham considers a measure as just if it has the tendency to increase happiness or to reduce pain. Measures taken on insecurity in Nigeria have continued to aggravate the level of sorrow and pains. The increased rate of armed robbery, kidnapping, terrorism, herdsmen/farmers clash and ritual killings have worsened the security situation in Nigeria. The decision of the Human Right Community to stage a nation-wide protest over insecurity is an indictment that the Government has failed to tackle the problems of Insecurity in Nigeria ${ }^{8}$. The amnesty programme introduced in 2009 was a just measure that curbed the terrorist act of the Niger-Delta militants. The decision of the Federal Government then alleviated the suffering of the people. As posited by Mill, Utilitarian are interested in calculating the consequences. Boko Haram insurgency in Nigeria is a product of poor-decision making. The role of the security outfits is primarily responsible for the orgy of violence by the Boko Haram sect. The extra-judicial killing of the leader of the sect in 2009 and the maltreatment of the members in the hands of the police are all factors that provoked the change of style by the sect who before then conducted their affairs peacefully. Nigeria cannot afford to close her eyes to the demand of the sect who have a large percentage of supporters among the people in the zone as well as the people in government. The combatants or the foot soldiers in the Boko Haram struggle are not the problem but the people in the region. The government should be courageous to embark on the imperative issue of restructuring Nigeria along the interests paramount to the various groups. Restructuring along the religion, cultural and ethnic divide is an imperative task and the government must be ready to take decisions that will guarantee the maximum happiness of the people in the north eastern part of Nigeria and the country as a whole. At independence in 1960, Nigeria recognized the diversity and the country was structured into three regions-the West, the East and the North and each region developed at its own pace.

The Nigeria Police is a critical factor in combating the security challenges in Nigeria. The Police Act ${ }^{9}$ provides that the police shall be employed for the prevention and detection of crime, the apprehension of offenders, the preservation of law and order, the protection of life and property and the due enforcement of all laws and regulations with which they are directly charged, and shall perform such military duties within or

\footnotetext{
${ }^{1}$.CFRN 1999 s 33(1)

. CFRN s17(2)

${ }^{3}$.CFRN s24C

${ }^{4}$ John Rawls, A Theory of Justice (University Press 1990)

5 . Brooke Noel More and Richard Parker. Critical Thinking McGraw Hill Education Publishers

6.CFRN 1999 ss131 and 177

${ }^{7}$ Not Too Young to Run Act, 2017

8 .'Falana Threatens Public Protests Over State of Insecurity' https://the nigerialawyer.com/falana-threatens-public-protests-over-state-ofinsecurity accessed 12 April, 2019

9 . Police Act Cap P19 LFN 2004 s4
} 
outside Nigeria as may be required of them. The operational control of the police resides in the president. The Inspector-General of the Police is an appointee of the President while the command of the police by the Inspector-General is subject to the directive of the President ${ }^{1}$. Every State in Nigeria has a Police Command under the Commissioner of Police. The Commissioner of Police is required to comply with the directions of the Governor of the State on the issue of security and public safety but the Commissioner of Police is not obliged to carry out the instruction promptly as he may seek further directive from the President of Nigeria. The insecurity in Nigeria as shown by the various forms of criminal activities is a confirmation that the police has failed in its statutory duty. The structure of command in the police, corruption, poor education, lack of modern equipment and ethnicity are among the factors that make the police a curse rather than a blessing in the architectural structure of security in Nigeria. There are instances in Nigeria where the police have been linked directly to the commission of crimes through the supply of ammunition or provision of information to criminals. The efficiency of the local vigilante groups in Nigeria in curbing criminal activities has proved that the State Police is an alternative to the present police system in Nigeria. The present structure of policing in Nigeria has no utility but rather it has maximised pains rather than pleasure. The state police is urgently required if Nigeria is not prepared for the restructuring of the federation.

Political office in Nigeria is the quickest way of affluence and wealth. Nigeria is a country where political office holders earn the highest remuneration than their counterparts in other countries of the world. This is the underlying factor for the violence that characterised the political process. The new species of crimes in Nigeria are fallout of a morally bankrupt political process. Political office should be used to advance the happiness of the greatest majority of the people instead of promoting the welfare solely of the political office holders. The utilitarian compass is that political office should be part-time and to be remunerated by sitting allowance. Politicians in Nigeria are entitled to severance allowance while some are even placed on pensions after leaving office. The contest for political office should be limited to people who genuinely wants to serve the nation and who are ready to sacrifice their personal pleasure. The monthly security votes allocated to the office of the President and Governors should be reduced drastically and where it is not reduced, the president/governors should give account monthly on how the vote is spent.

Administration of criminal justice in Nigeria involves decision-making. The decision of the court can be of utility where it makes anti-social behaviour a source of pain. Administration of criminal justice in Nigeria breeds recidivist in view of the light punishment imposed on convicts and in some cases because of technicality, criminals are let -off the hook. The Attorney-General of the Federation in Nigeria and the Minister of Justice at the federal level and the counterpart at the states are empowered to determine whether a suspect has a case to answer and where a suspect has a case to answer, the Attorney-General can discontinue a criminal proceedings by issuing a Nolle Prosequi. ${ }^{2}$ The criminal procedure is beclouded with technicalities which allow a criminal to escape justice. The judges are to reflect on the justice of the case rather than giving room to technicalities. The judges are advised to take a cue from the statement of Lord Denning-

My root belief of the proper role of a judge is to do justice between the parties before him. If there is any rule of law which impairs the doing of justice, then it is the province of the judge to do all he legitimately can do to avoid that rule-or even to challenge it-so as to do justice in the instant case before him. He need not wait for the legislature to intervene: because that can never be of any help in the instant case. I would emphasise, however, the word legitimately; the judge is himself subject to the law and must abide by it ${ }^{3}$.

The Rule of Law is imperative for security and Public safety. The law must be applied and interpreted to ensure equality before the law. The decisions of the courts must promote the greatest happiness of the greatest masses. This will make anti-social behaviour a source of pain rather than pleasure to the doer. Ethnicity, religion, corruption and political affiliations have dictated the course of justice in Nigeria. Judicial officers must be above board and must be courageous to interpret the laws objectively. The independence of the judiciary is imperative for social order. The executive must be ready to obey the order of the court. In Nigeria today, the Federal Government has a reputation for disobeying the order of the court.

The decision-making process by people in the government is neither based on any objective standard nor is it dictated by its utility. Some of the factors that influence decision-making by the political leaders in Nigeria are $^{4}$ :

(a) Desire to have victory over political opponents

(b) Ethnic consideration

(c) Safe-guarding future political interest

(d) Political favourites

(e) Sycophants

\footnotetext{
${ }^{1}$.Police Act Cap P19 LFN 2004 s10

2 .CFRN 1999ss 174 and 211

3 .Aguda, A, The Crisis of Justice (Eresu Publishers Ltd 1986) See also Denning LJ, The Family Story. (Butterworths Publishers 1981)

${ }^{4}$.Augustus Adebayo $\mathrm{Op}$. Cit
} 
(f) Political blackmail

(g) Intuition

(h) Juju and divination

The above factors influencing the leaders in government are of no utility but rather they are designed to advance selfish interests. The Federal Character Commission in Nigeria requires the government to take decisions for social solidarity in a way to ensure that political appointments reflect the cross section of the country. The appointment in Nigeria into political office and the civil service reflects the interests of the leaders to serve the interest of their ethnic or political group and not the overall interests of Nigeria. For instance the former Inspector-General of Police, Idris was the choice of the President, hence many competent senior officers were retired to pave the way for him. The president appointed a retired army officer to head the Custom service instead of appointing somebody within the service. The government mode of decision-making which is tailored towards satisfying the interest of the few is one of the albatross of security in Nigeria.

\subsection{Conclusion}

Utilitarianism as employed in this study advocates the utility of every decision made by the people elected to serve in government. Democracy is expected to bring comfort and not pain to the society. Insecurity has taken its toll on the citizenry in Nigeria from 2009 to date and from 2015 to date; the situation has become worse contrary to the expectation of the people. The democratic process in Nigeria is not tailored towards the greatest happiness of the greatest masses. Although the elected or appointed political office holders are not the square peg in a square hole, there are bureaucrats in government with expertise whose knowledge are not reckoned with for political expediency. The utilitarian compass contains measure that can cater for the demands of the heterogeneous society like Nigeria. The government must overlook ethnic or religion consideration and deal decisively with the problems of insecurity. In Nigeria, accusing fingers have been pointed at the president to the effect that the people responsible for majority of the crimes perpetrated are from his ethnic group and religious affiliation. The government should, therefore, take decisions that will bring the greatest happiness to the greatest number of the masses instead of pursuing the parochial interest of few that will continue to aggravate insecurity in Nigeria. The electorates must rise above personal interest in their decision -making when voting to elect people. The pedigree of aspirants and what the aspirants have to offer to the society must be used to assess the capability of the aspirant. There is the need to revisit the Constitution and raise the academic standard for anybody aspiring to become the leaders whether at the Federal or State levels. The people should be bold enough to rise against leaders that are notorious for disobeying the order of the court. The Rule of Law must be the guiding post for the three arms of the government. 